\title{
Countering Insurgencies and Violent Extremism in South and South East Asia. Ed. Shanthie Mariet D’Souza. London: Routledge, 2019.
}

Sahar Khan, Ph.D.

Cato Institute, khansahar1@gmail.com

Follow this and additional works at: https://digitalcommons.usf.edu/jss

pp. 103-106

\section{Recommended Citation}

Khan,, Sahar Ph.D.. "Countering Insurgencies and Violent Extremism in South and South East Asia. Ed. Shanthie Mariet D'Souza. London:

Routledge, 2019.." Journal of Strategic Security 14, no. 4 (2021) : 103-106. DOI: https://doi.org/10.5038/1944-0472.14.4.1991 Available at: https://digitalcommons.usf.edu/jss/vol14/iss4/7

This Book Review is brought to you for free and open access by the Open Access Journals at Digital Commons @ University of South Florida. It has been accepted for inclusion in Journal of Strategic Security by an authorized editor of Digital Commons @ University of South Florida. For more information, please contact digitalcommons@usf.edu. 
Countering Insurgencies and Violent Extremism in South and South East Asia. Ed. Shanthie Mariet D'Souza. London:

Routledge, 2019. 
Khan,: Countering Insurgencies and V iolent Extremism

\title{
Countering Insurgencies and Violent Extremism in South and South East Asia. Ed. Shanthie Mariet D'Souza. London: Routledge, 2019. ISBN 978-1-138- 61555-7. Illustrations. Contributors. Contents. Index. Pp. 376.
}

\author{
By Sahar Khan, PhD \\ khansahar1@gmail.com
}

Countering Insurgencies and Violent Extremism in South and South East Asia is an impressive edited volume featuring academics, journalists, policy analysts, and practitioners who have dived deep into the various states' counterinsurgencies strategies and operations. As the world watched the United States fumble out of Afghanistan, the book is prescient and well-positioned to inform both scholarship and policy alike especially if policymakers are willing to be open-minded.

This collection focuses on past and present state responses to rebellion and non-state violence in an attempt to carve out lessons that can be applied to future clashes. It does this in four sections. The first features chapters on emerging threats presented by Islamic State and affiliated groups, and violent extremism in Indonesia, Philippines, Myanmar, and the Maldives. The second section is perhaps the most uplifting collection of essays that focus on the durability of peace in post-conflict scenarios in Nepal, India, Singapore, and Malaysia. The third section highlights the ongoing struggles with counterinsurgencies in Afghanistan, Pakistan, and Thailand, while the final section dissects Sri Lanka's successful defeat of the Tamil Tigers as an example of a rare, yet achievable, victory.

The book's angle - analyzing past and present state responses to insurgents/militants/terrorists operating within its borders - is not new, but what makes this volume stand out is a nuanced starting point. Instead of beginning with questions like "What should be done?" most chapters start with "What problem is causing resistance?" When trying to understand insurgency and develop countermeasures, the starting point is vital. Too often, both policy and scholarly work focus on countering political violence like insurgency, militancy, and terrorism, without trying 
to understand why it began in the first place, resulting in inadequate and counterproductive - state responses. Three chapters in particular deconstruct the root causes of violent extremism effectively. Geoffrey Macdonald, Rhonda Mays, and Luke Waggoner anatomize the Indonesian state, and how the country's struggle with nationalism has created an environment conducive to violent extremism (pp. 62-70). Similarly, Bibhu Prasad Routray examines the Arakan Rohingya Salvation Army, the group that the Tatmadaw (Myanmar's junta) has been relentlessly targeting (pp. 77-79), and which is largely misunderstood, under analyzed, and mislabeled. Myanmar's most recent crackdown, which began in 2017, has resulted in thousands of Rohingyas fleeing to neighboring countries, and creating one of the largest refugee crises to date (pp. 80-85). The Naxalite movement in India is another case that has been in need of deeper understanding, which Samir Puri provides by uncovering the lack of political progress made between the Indian state and the rebels, something India doesn't like to focus on (pp.160-163).

Another important contribution of this volume is its deliberate - and successful - attempt away from "large-N studies." While of course useful for understanding and unearthing trends, large-N studies are not suitable for understanding ground reality and roots of political violence. Pakistan, a state that is routinely investigated in the realm of counterinsurgency, ends up being an outlier in large-N studies due to the uniqueness of its extremism's evolution. Marvin Weinbaum's and Anatol Lieven's chapters together provide a rich breakdown of Pakistan's challenges and struggles with legitimacy. On the other hand, the states of Nepal, Thailand, and Singapore would get lost in large-N studies, but Thomas Marks' and Mohamed Bin Ali's chapters explain the important lessons each has to offer. The case of Nepal illustrates how a peace agreement does not guarantee the end of covert struggle and how violence can become a shaping mechanism (pp. 109-152). The insurgency in southern Thailand demonstrates the importance of local demands and drivers of insurgency, which are often hidden due to limited access (pp. 276-284) while the engagement of Muslim community organizations to curb radicalization within Singapore highlight the importance, and need, for communitybased CVE programs (pp. 191-205).

Collectively, however, these chapters provide both an in-depth analysis of specific cases while also giving readers a bird's eye view of 
counterextremism research. The book, however, has two weaknesses. The first lies in its theoretical approaches. From an academic point of view, the variation in theoretical approaches is important, and highlights the complexity of counterinsurgency itself. After all, theory is not fixed and there is always room for improvement; for adjusting the lens by which to see the world. From a policy perspective, however, the theoretical variation is less useful; while it provides the reader with a sense of "hindsight is 20/20," it offers little comfort for analyzing ongoing counterinsurgencies worldwide. For example, Sameer Lalwani, looks beyond the military effectiveness literature when examining Sri Lanka's counterinsurgency victory over the Tamil Tigers. He effectively argues that it was not force deployment, insurgency attributes, and leadership, but was the Sri Lankan's government "new found material preponderance" (p.298) that led to the Tamil Tiger's defeat.

Lalwani's quantitative analysis is persuasive, and provides support to all those who advocate for providing militaries more money and resources for counterinsurgency operations - something US generals did routinely in America's 20-year war in Afghanistan. Lalwani's support for material preponderance, however, ignores the domestic political battles behind counterinsurgency, which play an important role in determining when and what resources should be allocated to the military. Alternatively, Andrin J. N. Raj's call to use ethnography and demography to counter violent extremism over law enforcement mechanisms and capacity-building (pp. 213-220) - which he finds useful when studying the ongoing threat of religious extremism in Malaysia - is well received.

The second weakness of the volume is the failure to view corruption as a systemic problem when it comes to counterinsurgencies. When describing Philippine's President Rodrigo Duterte's government's response to the Battle of Marawi, where Islamic State-affiliated insurgents turned the city into a battleground for month, Richard Javad Heydarian deftly explains the government's incompetence and deficits when it came to the crisis (pp. 39-58). Yet, where is corruption? In other words, aren't these failings in part related to the Philippine's infamous corruption that has eroded the state's institutions, and hence damaged their capacity in the process? Similarly, Antonio Giustozzi's chapter on Afghanistan sidelines corruption. His analysis of President Ashraf Ghani's quest for professionalization, reform, and institution-building is useful (pp. 229-234) but a full 
understanding of Afghanistan's political landscape can't be achieved without uncovering the deep corruption that all stakeholders are involved in. Kirklin J. Bateman chapter on the Maldives, however, is one of the few that stands out. He outlines Maldives' relationship with corruption, and how the legacy of patronage and corruption has hampered the current government's ability to understand the root causes of the growing extremism that is threatening the state's lucrative tourism industry (9397).

Overall, this is an impressive collection and a must-have for all who are interested in learning more about intricacies and complexities of countering insurgents and violent extremists in South and Southeast Asia. 